\title{
Reflections on an Experiment in Pragmatic Social Research and Knowledge Production
}

\author{
Liam Harney and Jane Wills
}

\begin{abstract}
This chapter reflects upon the lessons learned through an experiment in pragmatic social research conducted in east London in the United Kingdom in 2015. The experiment was designed to facilitate the formation of communities of inquiry involving diverse groups of people working on issues of common concern. Entitled the 'E14 Expedition', the project drew upon the pragmatism of the Chicago School of Sociologists and the work of Ernest Burgess, Robert Park and George Herbert Mead. It was also based on the earlier work of William James and John Dewey who highlighted the importance of acknowledging the way that multiple truths are always at play in the world, reflecting an inevitable pluralism of personalities, experiences and interests. The expedition tried to test whether, and if so, how, university researchers could work with a range of citizens to address public problems in a genuinely open way, listening to the full range of opinion and ideas. As such, the project exposed the extent to which academic social scientists are often deaf to political opinions that are believed to be misguided, confused and/or incorrect. The expedition also sought to explore the challenges of enabling citizen-led problem-solving action through participatory research and in this regard, it exposed the role played by the social infrastructure of pre-existing relationships, trust, shared interests and identity in underpinning and enabling effective collective action. The chapter advocates paying greater academic and political attention to the things that make public action and problem-solving possible, including being open to different ideas and beliefs, and nurturing the social relationships that enable democratic behaviour and practice.
\end{abstract}

KEYWORDS: Publics; Social Infrastructure; Puralism; Conservativism; Problem-Solving; Democracy.

\section{Introduction}

This chapter describes an experiment in pragmatic social research that took place in east London, UK, lasting for 14 months from January 2015. The experiment, called the E14 expedition after the postcode covering the area of Poplar and the Isle of Dogs (see Figure 1), involved recruiting volunteers who were interested in joining a new community initiative to foster local relationships and identify shared interests and issues around which to campaign. Conducted in two phases, the first focused on thinking about the local community and its history, and the second was designed to develop solutions to pressing concerns. In the event, two different groups of people were involved; 24 people took part in phase one and 19 in phase two. However limited in scale and depth, the E14 expedition provided a mechanism to think about what pragmatic social science might look like. The research was focused on understanding the infrastructure needed to allow people to engage in 
community-based relationships created for research, knowledge production and action. It highlighted questions about the role to be played by academics and the implications for epistemological practice. While the expedition was designed to have significant benefits for those taking part, providing training, new opportunities and the chance to learn new skills, it also provided an opportunity for careful thought and learning about the processes, challenges and potential benefits involved in conducting pragmatic social research through the establishment of communities of inquiry.

Figure 1: The E14 expedition area: Poplar and the Isle of Dogs, London, UK

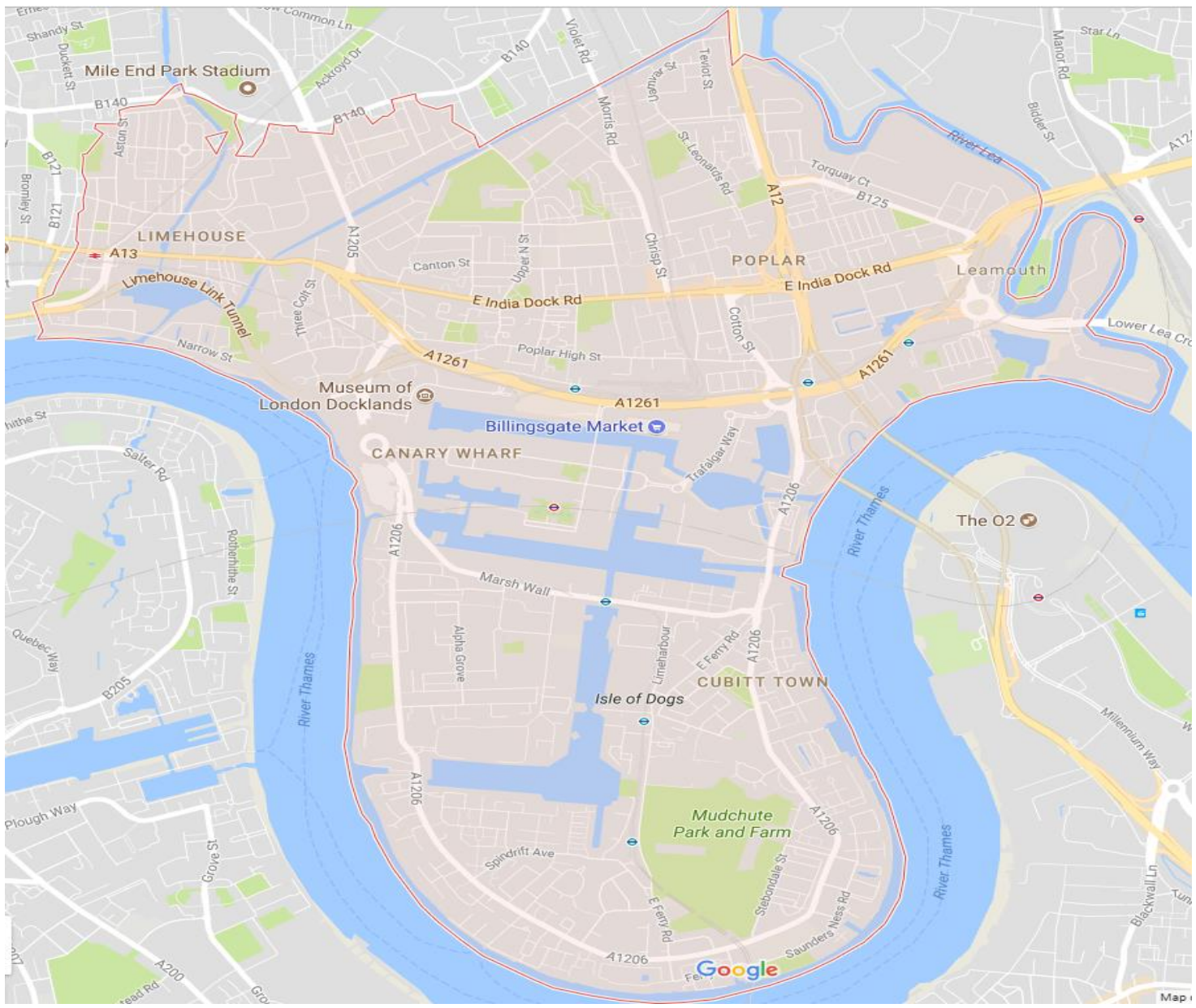

In many ways this project built directly on the work of earlier generations of pragmatic social scientists such as Robert Park, Ernest Burgess, George Herbert Mead and Herbert Blumer, and their work is outlined in the opening chapter of this book. Being located in the discipline of Human Geography, however, the E14 expedition also sought to follow in the footsteps of Bill Bunge who similarly tried to bridge the gap between the university and its local community in Detroit during the late 1960s. In his Geographical Expedition, Bunge deployed university resources (staff, students and 
research expertise) to work with a broad-based community organisation and its leadership to expose the pressing needs of a local community (Barnes, this book; Bunge, 1969, 1971; Heynen and Barnes, 2011). Building on the traditions already established in Human Geography in particular, and social science more generally, the E14 expedition sought to operationalise and test this existing 'model' of pragmatic social research. As outlined in the opening chapter of this book, this involves a number of key principles including: (1) Starting from the provocations of the field and the community living there rather than basing research on the interests of the academy or the particular academic; (2) Working with a particular community to identify the issues of pressing concern from their point of view and then co-producing possible solutions; (3) Conducting research and creating new knowledge as part of this process; and (4) Building the capacity of participants and strengthening the democratic voice and power of the community to act and resolve these concerns.

As such, pragmatists advocate that the processes of research and knowledge production are always embedded in a particular community (Rorty's (1991) 'ethnocentrism') as part of ongoing efforts to solve collective concerns and find ways of living together (Dewey's ([1927] 1954) notion of 'publics' or 'communities of inquiry'). This is particularly pertinent to a geographical imagination and as Dewey $([1920]$ 1957, 166/7) put it almost 100 years ago: "We cannot seek to attain health, wealth, learning, justice or kindness in general. Action is always specific, concrete, individualized, [and] unique. And consequently, judgements as to acts to be performed must be similarly specific."

The pragmatic approach to research and knowledge production re-orientates the focus of academic inquiry away from the campus, international conference circuits and publishing houses towards the society in which the academic is already embedded. It directs academics away from lone scholarship and a refinement of expertise towards active partnership and collective endeavour in the process of producing new ideas. Perhaps most troublingly for many, it also advocates that the work is forwardlooking and creative (Gergen, 2015; and for a critique see Wolfe, 1989). Moving beyond the dominant focus of academic scholarship on realism and critique, pragmatists advocate an epistemology that is proudly political with a small p; in the spirit of post-representational thought, their work is focused on generating ideas that can reconfigure the world.

In this vein, the expedition was an attempt to facilitate the formation of publics comprising diverse groups of people focused around issues of common concern. The expedition was based on the pragmatic notion of multiple truths existing in the world, the validity of which are determined not by appeal to an a priori moral compass or external reality, but by the strength of belief and the action they enable. As such, the expedition sought to explore how the pluralism of the citizenry and its knowledge could be adequately respected in pragmatic social research. 
The approach taken to this experiment was inspired by the model of broad-based community organising developed by Saul Alinksy, in which people from a range of backgrounds, but inhabiting a shared geographic area, put aside their differences in order to pursue the common good (Alinsky, 1971; Schutz and Miller, 2015). In this model, major differences of outlook and values are effectively 'parked' and left at the front door of the public realm in which areas of common concern and interest can be identified and acted upon (Wills, 2012).

In developing this work in E14, Harney intended his role as an academic to be a facilitator of relationship-building and dialogue amongst a community of inquirers. Importantly, in order to respect the pragmatic notion that multiple truths exist in the world, the expedition explicitly sought not to choose the issues for inquiry, or the social identity of the inquirers before the study, but to cast the net wide to gather a group of people from various communities and social worlds and allow shared issues to emerge through conversation amongst them. Place, rather than other forms of social identification, such as class, sexuality, gender, ethnicity or religion, was deployed as a relatively neutral lens through which to gather citizens and form a community of inquiry, ensuring that the academic had minimal control over which citizens' knowledges were articulated through the project and whose interests it potentially served. As Lake (2014) argues, all inquiries are 'moral inquiries', filtered through a priori ontological outlooks that shape the framing of issues, ideas and action. In the interests of democracy, the expedition was designed to minimise the ability of the academic and academic interests to shape the moral nature of inquiry in E14.

In this sense, the expedition was designed as an alternative to much participatory action research (PAR) that is conducted within the social sciences in which specific worldviews, values, identities and interests (often in line with those of the academic leading the project) are used as moral framings prior to processes of collective inquiry (see Harney et al, 2016 for a fuller discussion). The expedition was about testing whether, and if so, how, universities could work with a range of citizens to address public problems, instead of selecting and prioritising the experiences, knowledge and interests of certain groups of people who are given moral priority by mainstream social science (such as women, LGBT people, and ethnic and racial minorities.). The expedition was based on an understanding that, whilst valuable and well-meaning, approaches to engaged research and action with citizens that focus primarily on these social categorisations are limited in scope and potential, serving to ignore and exclude a large range of other people, experiences, ideas and beliefs. The expedition thus sought to experiment with the ways in which pluralism could be respected through pragmatic social research and it is this that we explore in the first part of this chapter. We then go on to look at the challenges encountered in regard to the pragmatic focus on action. 


\section{Building a diverse community of inquiry}

In the run-up to the launch of the E14 expedition, Harney spent time visiting local community groups and asking people to volunteer to take part. An application form was left with a range of organisations including community centres, children's centres, churches, housing associations, libraries, mosques and schools. Phase one of the project was pitched as a project to build relationships between residents in the area, to explore people's experience of living there and to identify pressing local concerns that would form the focus for research and action in phase two of the project. Engagement was certificated by Queen Mary, University of London, and following the processes of application, selection and attendance, 20 women and 4 men engaged in the project that ran from late January until the end of May 2015. These individuals ranged in age from 16 to 69 and included atheists alongside active Christians, Jews and Muslims, established residents from the white and Bengali-British populations, as well as immigrants from America, Brazil, Lithuania, Italy, Nigeria and South Africa (with 11 different nationalities included in total). The early training sessions focused on the power of story-telling to build relationships and rethink possible futures. Participants were asked to talk to their friends and neighbours and listen to their stories of living in E14, recording them for a book. ${ }^{i}$ Rather than telling one story, the expedition explicitly sought to capture the diversity of local experience, holding a session for collective deliberation about the range of stories collected, trying to ensure that everyone was able to speak (see also Cahill, 2007). The narratives were then compiled into a book with pictures of many of the 60 people interviewed, published as E14 Our Stories, and launched at a local school on 30 May 2015 (Agugu et al, 2015).

Participants in the expedition were subsequently interviewed to explore their experiences of the project and to enable Harney to reflect on the way that this phase of the expedition impacted on local relationships and community-building and the wider lessons for pragmatic research. These interviews raised important issues and questions about pluralism, and although most participants reported that they valued having the space to talk about their experiences of diversity, one respondent stood out as she felt unable to articulate her concerns and we consider her experiences further below.

In the group discussion, people seemed to be able to express their feelings about living in an area marked by the co-presence of many different kinds of people. As an example, one Jewish participant reported feeling worried about putting a Mezuzah on her door, saying "I want to hide from people, I don't want my neighbours to know." While she welcomed the chance to talk to Muslim participants involved in the expedition, saying "I want this conversation to continue", she felt vulnerable as a Jew living in a largely Muslim area. Similarly, two members of the group shared that they had suffered 
for being gay, one from homophobic verbal abuse and another by family rejection, and the group expressed their support for these individuals, albeit within a rather unrealistic space where the people involved were largely willing to leave their prejudices at the door in order to take part in the first place.

Indeed, it was the individual interviews with participants that revealed the potentially surface-level nature of these group conversations, as the experience of Barbara highlights. In her interview she told Harney that she felt the project "was being hijacked" by the Muslim interest in E14. She felt that the wider coalition between left wing political activists and the Muslim community in the area (see also Dench et al, 2006) had left her feeling that no-one represented her interests or those of her community. She argued that her politics - described as "Conservative with a capital C" - put her at odds with all of the participants in the group who were receiving benefits and/or working in the public sector and who reflected what she called a "left-wing point of view". Given the balance of opinion in the group she reported that "there were many times when I just kept my mouth shut" saying: "I was totally outnumbered. There wouldn't have been a person who agreed with me. Why would I put myself in that position? It's like putting the Christians into the Coliseum with the lions, you know? I was not going to be a Christian, OK?"

Barbara appeared to be engaging fully in the project, she took part in the conversations and shaped the debate about the story of E14, but she clearly felt silenced by the group dynamic. Her experience raises difficult questions about how to respect the principle of pluralism in pragmatic research, particularly when it takes place against the backdrop of profound divisions in the wider community and society at large.

It could be argued that this situation could be remedied by effective facilitation skills on the part of the academic, working to ensure that all voices are given an equal hearing in the conversation (Cahill, 2007). Yet we feel that this problem reflected wider forces than were at play within the group and the project. Barbara felt outnumbered in the group; she felt herself to be in a minority in regard to her conservative views in a room that she perceived to have 'left-wing' leanings. Arguably, Barbara's predicament was reflective of a situation in wider society in the UK, in which conservative views and values have been culturally and politically marginalised in favour of more progressive ideas. David Goodhart (2017) provides a convincing account of this, analysing two broad 'value clusters' that now exist within UK society. He suggests that the citizenry can be split, broadly, into those who possess an 'anywhere' worldview and those who can be classified as 'somewheres'. The former value independence, mobility, multiculturalism and cosmopolitanism, whilst the later place higher value on stability, tradition and familiarity. He argues that one of the key factors shaping a 
person's outlook along these lines is their experience of mobility, mostly associated with uprooting from one's family, communities and place of birth when attending a residential university at a young age. For Goodhart, the experience of going to university, having to make new friends and be surrounded by other students from across the country and the world, coupled with the content of the courses taught in the social sciences and humanities, lends itself to the development of a more progressive 'anywhere' worldview. In contrast, 'somewheres' tend to have stayed within close proximity to the home they grew up in, are less likely to have been to university and more likely to have maintained ties with family and friends developed from an early age, and this tends to promote more conservative values.

Goodhart argues that 'anywheres', whilst fewer in number than 'somewheres' (for Goodhart, the ratio is about 30:70), disproportionately make up the ranks of the political and cultural elite in the UK. This is due to their possession of university degrees and their entrance to middle class networks that give them access to jobs in the professions, politics, the media and government. For this reason, those with 'anywhere' worldviews are culturally and politically dominant, asserting their worldview and values over 'somewheres'.

Goodhart's controversial analysis of UK society has highlighted the crucial role that universities play in maintaining this cultural split as places that socialise and educate the next generation of 'anywheres'. Given that university graduates disproportionately make up the ranks of political and cultural professions, this has implications for democracy, with the 'anywhere' worldview having disproportionate influence over public decision-making processes, public discourse and political power. As such, universities play a major role in reproducing the gap between large numbers of ordinary citizens and a smaller political elite. This is also reinforced by the ideas that students are exposed to in their classes. Within the social sciences, these ideas and values tend to be mainly those associated with a left-wing or 'progressive' worldview, stemming from the radical politics and ideas that became dominate in the academy from the 1960s onwards (Williams, 2016).

For some conservative thinkers the dominance of 'anywhere' or progressive worldviews in universities, politics and the media has created a climate in which large numbers of ordinary citizens feel un-represented or ignored by mainstream politics and culture (Lasch, 1991; Williams, 2016; Slater, 2016). This feeling of having been ignored over the past few decades partly explains the vote for Brexit in the United Kingdom and the election of Donald Trump in America. These votes shocked the political and cultural establishment as they asserted 'somewhere' or conservative values in the interests of citizens who felt they had lost out because of the policies of 'anywhere' elites (Inglehart and Norris, 2016; Goodhart, 2017; Chwalisz, 2015). 
Going back to the expedition, Barbara's experience reflected her perception of the dominance of more progressive values in the group. Whether or not the other participants held such views was unclear, but Kathleen's sense of being a minority for holding more conservative views was probably symptomatic of the cultural dominance of more 'progressive' values in society at large. In the local context, east London's party politics has also been shaped by a contest between 'anywhere' and 'somewhere' worldviews that began in the late 1970s. The east end has been a Labour party stronghold for decades with the party having its roots in the trade unionism of the docks at the turn of the $20^{\text {th }}$ Century. However, Dench et al (2006) explain how in the late 1970 s, the party became divided between activists and members who espoused and sought to advance more conservative values, and those with more progressive values. This divide was centred around the questions of social housing allocation at a time of large-scale immigration of south Asian people to the area. The conservatives were pushing for council tenancies to be reserved for the sons and daughters of the established population, whilst the progressives sided with the growing Bangladeshi Muslim community and their perceived right to housing as homeless, overcrowded, migrant families.

This struggle played out over years, provoking a period of instability in local politics, including the election of a Liberal Democrat council for the first time and the rise in popularity of the British National Party, both of which attempted to represent the interests of the white working class against an increasingly influential Bangladeshi Muslim community (Dench et al, 2006; Foster, 2011; Pile, 1995; Torode, 1994). However, with support from new housing legislation, the progressives won out and homeless migrant families were given statutory rights to council housing above the children of existing tenants. From the 1990s onwards, a progressive worldview and set of values has shaped the local Labour party in Tower Hamlets, facilitated by a (somewhat tumultuous) alliance between left-wing, progressive activists and the highly organised Bangladeshi community (Dench et al, 2006).

Given this history, Barbara deemed her conservativism to be a minority stance amongst the other participants of the expedition, and indeed, the wider community too. Regardless of whether one shares Barbara's view, this reflects a democratic culture in which certain people do not feel comfortable articulating their opinions and ideas as they clash with the perceived mainstream view. And this is not just a case of an extreme minority view; the E14 area is home to many people who, like Barbara, feel that change in their community associated with large-scale migration of people from different cultures has been negative for them. From a pragmatist perspective, the dominant culture within politics and academia shows little respect for the truths of people like Barabaraand this is something that needs to be addressed. 
Although it was conceived as a way of overcoming the dangers of hard-and-fast ideologically-driven beliefs in the wake of the violence of the American civil war (Menand, 2011), pragmatism has often been accused of silencing difference and power relations in the quest for the middle ground (see Saegert, this volume). However, this argument is usually made in relation to the experiences and views of oppressed groups of people with whom progressives usually align themselves (Brandom, 2009; Fraser, 1989, 1990) rather than those with conservative views. Moreover, despite such differences, pragmatism would also urge a 'forward-looking' response. In a fast-changing community of diverse interests like east London, text-book pragmatists might argue that there is little practical benefit in revisiting battles that have been and gone rather than looking ahead. As a tradition that urges us to focus on the consequences rather than the antecedents of our ideas (Brandom, 2009), pragmatist thought would advocate finding areas of common ground around which to work despite deep-felt difference. In this regard, the focus of the E14 expedition, particularly of phase two, was to move on to find areas of shared interest around which participants could develop new ideas about working together. The whole point of the project was to find new ways of going forward together.

However, as Barbara's case shows, certain differences are too significant to be pushed to the side (and she chose not to participate in phase two of the expedition). Her conservatism, whilst probably developed from a young age, had been further compounded by her experiences of living in east London during a period of widespread social change and was likely reinforced by her engagement in the expedition. Given the sharp -and widening - divisions in national political culture, and the lack of acceptance of conservative views in mainstream political discourse, it proved very difficult to do justice to the pluralism of opinion via pragmatic research. Moreover, these divisions have arisen in part because there is little willingness to listen to and respect the 'somewhere' worldview (Slater, 2006; Williams, 2016; and for an interesting pragmatic argument about similar trends in the USA see Rorty, 1998). Arguably, a major contributor to this culture of division in modern democracies is the way that knowledge has been generated, taught and consumed within UK universities, especially in the social sciences. For too long, social science has favoured the reproduction and propagation of a narrow range of 'progressive' ideas, values and outlooks amongst its students, through the academic orthodoxy of critical theory, and the derision of ideas and perspectives that do not fit this orthodoxy (Williams, 2016). This has shaped a rising generation of elite actors who have little tolerance for alternative perspectives. We need only reflect on the treatment of those citizens who voted for Brexit and Donald Trump to see this intolerance in action; these citizens were branded as 'racist' or 'stupid' in the blink of an eye.

This raises serious questions about what the social sciences can do to change this culture and foster more democratic attitudes of mutual respect, reasoned debate and attempts at understanding 
different perspectives. The approach taken by the expedition of seeking to park differences and find common ground did not work in this case. Certain differences are too significant to ignore or put aside and attempts at finding the common good may merely serve to avoid difficult conversations and encounters, and ultimately this reflects the way in which dominant values and ideas are imposed over minority ones in the creation of public narratives and debate (Cooke and Kothari, 2001; Young, 1990, 1996, 1997).

Progressive and conservative worldviews have always co-existed and each has had great effect in shaping the world (Haidt, 2012) and the pragmatist social scientist should feel compelled to take them both seriously. However, there is a lack of coverage and fair portrayal of conservative views and the citizens that possess them, in the social sciences. For the good of democracy, we need to remedy this. Academics need to be encouraged to respect and value these beliefs and attempt to understand the experiences that give rise to them. This means listening to and attempting to understand views that might make academics feel uncomfortable. It also challenges social scientists to help articulate the views of those they disagree with, as a democratic good in itself. This might mean serious interviews with the 'forgotten' citizens of the UK and USA, not as a move to deconstruct and re-interpret their sentiments from a progressive perspective, but as a way of giving them voice within the academy and wider public domain. It also means transforming universities into places where a range of conflicting, divergent and competing worldviews, beliefs and values can gain a fair hearing, rather than the knee-jerk dismissal or deconstruction of unorthodox knowledge (Slater, 2016). The pragmatic notion of multiple truths underlies such a social science and it is up to academics and students to help realise this broader perspective.

\section{The value of community for pragmatic social science and the limits of the activist imperative}

Advocates of pragmatism re-envisage university social science as a vehicle for the propagation of democracy, active citizenship and good public policy (Bohman, 2002; Boyte, 2003). Rather than determining the focus of research in advance of doing the work as is usually done in dialogue with other academics in a particular field, there is a strong case to be made for research that is done in partnership with a particular community. Given that social scientists are already in the business of creating ideas that have powerful effects in the world (Gibson-Graham, 2008; Law, 2004), the pragmatist approach urges that these ideas are directed to ends that are rooted in the public interest of a particular community (Lake, 2017a, 2017b). Doing this well requires maximum reach in the community, embracing diversity, listening to the breadth of opinion and devising ideas that can bring that community together around a shared future (Bernstein, 2010; Putnam, 1995; Rorty, 1989; Westbrook, 1991, 1989). 
The expedition sought to do this in E14, yet as seen above, we encountered significant challenges in relation to incorporating the full range of opinion and we also faced challenges in relation to the ability of the community to engage in any type of public action. Interviews with participants exposed the extent to which many people joined the expedition simply because they wanted to build relationships with other people in their locality. As one respondent put it: "I got involved in the E14 project because I thought it was a brilliant project, a great way to connect with people and get to know people as well." A number of longer-established residents argued that people were more connected in the past and the rapid pace of local change had eroded neighbourhood relations, prompting them to get involved and do something about it. Moreover, participants reported using the story-telling project as a cover to approach their neighbours in a way that had not been possible before. Talking about her long-held desire to chat to her neighbour, one participant said "E14 stories gave me a reason to knock on his door, it gave me a cover story ... a context as to why I wanted to have a chat with him." Having started a conversation with her neighbour, this participant found out about his personal difficulties with depression and felt much more connected to him as a result. Others reported feeling emboldened to approach people they saw at school and church as a result of the project and given their geographical proximity, it then became easier to cement these relationships over time through regular encounters in the locality.

At its most basic, the E14 expedition facilitated new relationships between the participants and their neighbours, and between participants within the group, as well as through sharing the individuals' stories via the book. The project illustrated the extent to which place can provide the ground for the formation of relationships between local residents, even when there is rapid turnover, diversity and tension in the population (Paasi, 2003). While the project recognised that the people of E14 exemplified Massey's (2005) notion of the 'thrown-togetherness' of people in place (see also Amin, 2004), it also demonstrated the extent to which sharing space can facilitate the creation of a new shared story, however diverse the origins of each person involved (Wills, 2013).

However, in phase two of the expedition, when action teams were formed around specific issues, the lack of social connections between participants and residents more widely became apparent as a key factor preventing successful coordinated action. One action team's experience in particular serves to highlight this. A team was formed to address the issue of a group of young mean hanging around a housing estate in Poplar, intimidating neighbours and engaging in anti-social behaviour such as drug taking and urinating in public stairwells.

This issue was extremely localised and specific to residents of one particular block of flats on the estate. Sabu, who lived here and took part in the expedition, tried to rally his neighbours to do 
something about this. He was starting from a very difficult position as he lacked deep relationships with his neighbours from which to initiate collective action to challenge the problem. His involvement in the expedition gave Sabu the confidence to knock on his neighbours' doors to start conversations about the problem and many admitted it was an issue they cared about, but he struggled to get further than this, with people fearing the risks of taking action and choosing not to get involved for the safety of their own family. Sabu ultimately failed to generate a positive response from his neighbours and the problem continued.

This example helps to illustrate the reluctance of most people to take collective action to address issues that affect them and the effort that would be needed to achieve any change. It highlights the way that most people tend to cope with things that are not going well in their lives. They try to get on with things and while each household in Sabu's block experienced the anti-social behaviour of the group of boys, they did not think of it as a problem that could be tackled by them. The problem remained painful but private, and despite his limited efforts, Sabu was not in a position to change this. The lack of relationships between Sabu and his neighbours served to foreclose the possibility of coordinated action around the issue and this aspect of the expedition highlighted the importance of having strong social relationships to facilitate publics (Dewey, 1927; Putnam, 1990).

This is an issue for pragmatic social research because without strong relational foundations and a public culture amongst citizens, collective inquiry and problem solving are much harder to facilitate (Barnett, 2008; Bridge and Watson, 2011). To illustrate this, Calhoun (1983) uses the example of the UK miners' strike in the mid-1980s as an example of public-formation that reflected the strong communal ties, feelings of familiarity and shared interests of the mining communities, which had been fostered over generations. Existing social relationships gave people the strength to act in a situation of high risk and uncertainty, providing a strong common identity and sense of solidarity that could then travel to shape wider debate. A similar example of this was the development of trade unionism amongst the dock workers in east London during the early 1900s and this fed into the local Labour movement in which the community supported their local politicians who they perceived to act in their interests (Booth, 2009, Butler and Hamnett, 2011).

There were no guarantees for this type of public action, but the existence of a well-connected placebased community acted as a fertile ground from which organisers and activists could mobilise people around a vision of a different future. In the 'old' east end of London people were connected through close neighbourly bonds, with extended families inhabiting the same geographical area, facilitating connections and a sense of familiarity amongst neighbours. People were also united by a shared Christian faith and its associated traditions and rituals. Moreover, key social spaces such as 
pubs provided the settings for repeated, mundane social interactions, weaving together the lives of local people (Young and Wilmott, 1957; Gavron et al, 2006; Forrest, 1999; Koch and Latham, 2013; Studdert, 2016).

Today the area is very different, having undergone major demographic change since around the 1970s, with waves of in- and out-migration fragmenting the community. The docks declined and thousands of people lost their jobs, devastating the local economy. Families that had lived in the area for generations left for better opportunities elsewhere, mainly moving to Essex and Kent. Newcomers arrived not just from South Asia, but Africa, the Caribbean and Eastern Europe, whilst new middle-class migrants arrived from Western Europe, the USA and other parts of the UK to work in Canary Wharf. E14 is now a fragmented, super-diverse place, home to various, sometimes overlapping, but often segregated communities. Social ties between neighbours are much weaker than in the past, owing to increased differences in identity, experience and interests amongst individuals (Butler and Hamnett, 2011; Colenutt, 1991, Foster, 2011, Vertovec, 2007).

Within this context, the E14 Expedition's attempts to facilitate collective action around shared issues appear somewhat naïve. The social foundations needed for public formation were too weak, and all three action teams failed to achieve a clear 'win' through their efforts. Up against the power of professionals, bureaucrats and businesses, and the dominant social forces, these nascent teams of citizens from different social worlds were always fighting an uphill battle. Moreover, this experience raises important questions about the 'activist impulse' that underpins much pragmatic thought and its application in social science.

In part, the focus on collective action reflects the particular roots of pragmatic ideas as they developed during the late nineteenth and early twentieth century, encompassing the traditions of liberalism and utilitarianism, Protestantism and progressivism. Lamenting the space vacated by the once-powerful social gospel, the early pragmatists expressed a faith that everyday democracy would provide the grounds and mechanisms through which to ferment civic virtue and a new moral order (Dewey, [1920] 1957; Putnam, 1995; West, 1989; Westbrook, 1991). As Dewey (1957, xxxiv) wrote when reflecting on his mission to reconstruct philosophy in the wake of growing secularization, he was responding to the "challenge to develop a theory of morals that will give the world positive intellectual direction ... in developing the practical - that is, actually effective - morals which will utilize the resources now at our disposal to bring into the activities and interests of human life, order and security."

In his vision, Dewey saw inquiry as providing a mechanism for the creation of ideas about society that paralleled the self-correcting model of science developed in the wake of Darwin's arguments 
about adaptation. Rather than providing metaphysical certainties, philosophy was to be reconstructed to help people adapt to their changing environment. To be human was to be provoked to inquiry and this creative intelligence was about learning through doing, having new experiences, and developing the resources to change the world.

There is, of course, something profoundly un-pragmatic about the development of a pragmatic approach to social research that is pre-committed to this vision of creative intelligence and the importance of inquiry. Despite loud proclamations of anti-foundationalism, pragmatists sometimes appear to be advocating a foundational approach to doing social research (Cavell, 1989; Diggins, 1989; Fish, 1989; Wolfe, 1989). As we have seen, there is a commitment to the community of inquiry, to the self-mobilising activist who is able and willing to join these communities, and to the forward-looking spirit that might motivate such engagement.

Yet, without adequate social infrastructure and relational foundations, collective action at a scale to secure meaningful change is near impossible to achieve. Moreover, reflecting on the case of E14, it is our argument that it is this imperative for action, change and progress that is (in part at least) to blame for the breakdown of community in the area. Post-war slum clearance programmes of the British labour government fragmented tight-knit, working class communities; open-border migration policies have enabled high flows of in-migration of people from starkly different cultures and places to the area, and free market economic and housing policies contribute to demographic change and population churn, and promise further community break-up and change over time. Whilst pockets of community and local connection do still exist, E14 today is characterised by a sense of transition, instability and constant change. For pragmatists, this should pose serious questions about the future of democratic life for the areas' citizens.

In this regard, the E14 expedition had much in common with other academic-led projects that deploy participatory research methods to co-produce ideas for change with insufficient attention to securing the power needed to generate change (Harney et al, 2016; Pain and Francis, 2003). In this vein, we have become sympathetic to less activist-oriented versions of pragmatism as well as conservative ideas that reject any necessary association with problem-solving and progress (Cahoone, 2002; Lasch, 1991). For these thinkers, there are dangers in the activist impulse, and much to be celebrated about being left alone to get on with living and loving rather than being told what to do (Oakeshott, 1962; Studdert and Walkerdine, 2016). Our experience with the E14 Expedition chimes well with these views and we would argue that there is real value in re-focusing pragmatic research less as a tool to form publics for action, and more to promote and develop the conditions that allow for democratic engagement and renewal. This would demand attention to the 
diversity of experience and opinion, and of listening to and disseminating a diversity of views, without any imperative to action. Should the process identify ways in which people want to act around their concerns that would be welcome but not imperative to pragmatic success.

Indeed, in Rorty's (1991) re-invention of pragmatism, the focus was shifted to the creation of new public narrative rather than seeking to root this narrative in the labours of a community of inquiry. Rorty developed a bifurcated understanding of the private and public in which "the demands of selfcreation and of human solidarity [are] ... equally valid, yet forever incommensurable" (Rorty, 1991, xv). Private irony was ill-suited to the public good but for him, such human solidarity was "to be achieved not by inquiry but by imagination, [by] the imaginative ability to see people as fellow sufferers" (op cit, xvi). As he put it: "If one takes the core of pragmatism to be its attempt to replace the notion of true beliefs as representations of 'the nature of things' and instead to think of them as successful rules for action, then it becomes easy to recommend an experimental, fallibilist attitude, but hard to isolate a 'method' that will embody this attitude" (Rorty, 1991, 65-66).

This spirit informed Rorty's interventions into American politics in which he advanced the process of 're-description' or creating 'new vocabulary', in order to foster solidarity for the public good. This vision of pragmatic scholarship no longer relied on Dewey's problem-solving publics or communities of inquiry but rather advocated deploying an emotionally-charged narrative to create a better world (Rorty, 1991, 1998). While some have tried to defend a form of democratic realism or naturalism as the basis from which new ideas can emerge (Bernstein, 1983, 2010; Kloppenberg, 1989; Putnam, 1992, 1995; Westbrook, 1989), Rorty and others prosecuted a linguistic pragmatism that is realised in community but not produced by any particular community of inquirers (Brandom, 2009;

Malachowski, 2010). This approach reflects Dewey's commitment to liberal democracy, and is more akin to his own political activism in a wide range of organisations and journalistic writings (Barnes, 2008; Westbrook, 1991), without adopting his approach to inquiry.

As a result of our experience, we would argue for a two-pronged approach in pragmatist social research. One prong would follow Rorty's lead in helping to create narratives that value the very things that make democracy possible: relationships, community, tolerance, and respect for alternative views. Such narratives might appear to be more conservative than the approaches currently favoured and deployed within the social sciences, and whilst we are not calling for the clocks to be turned back to the 'good old days' of tight-knit communities of tradition, there is much to learn and value from communities, past and present, where social infrastructure helps enable everyday civic engagement and lays the foundations for potential collective action. As a counter to the dominant 'anywhere' narrative that shapes western democracies, in which progress, free 
movement of people, progressive ideology and political dogma are championed, a more conservative approach that sought to protect community, familiarity and stability, might heal some wounds and better protect our democratic inheritance.

Coupled with this approach is the second prong; the need for more engagement with citizens in the creation and articulation of ideas, beliefs and values, some of which might make us uncomfortable, to enrich public discourse and help develop public narratives that are based upon and can resonate with the lives of ordinarypeople. This type of social science might place less emphasis on immediate problem-solving action as is often evoked in arguments for community-based inquiry or participatory research, but rather situate the university and its scholars as a conduit for sharing of situated knowledge and experience as part of the democratic process (indeed, we have made similar arguments in relation to the role of growing numbers of Community-University Partnerships that can help to facilitate this, see Harney and Wills, 2017).

Committing to this kind of social science would predict change happening over generations, rather than the months or years we might more usually expect. Embedding research and scholarship in relationships, and in relation to the particular field in which social scientists find themselves, requires a long term perspective and will depend upon relationships. However, the potential prizes are much bigger than those attached to current forms of research, and it would require challenging certain established orthodoxies in knowledge generation and social action. This approach could help to achieve some of the promises of pragmatism old and new.

\section{References}

Agugu, D. Al-Aza, Z. Binboga, Z. Bujauskiene, J. Burbridge, C. Castro, S. Contreras, L. Chowdhury, S. Di Trapani, G. Harney, L. Herron, K. Miah, R. O’Sullivan, J. Patrick, J. Paul, P. Quinn, P. Rab, M. Rahman, N. Rodrigues, J. Siddika, A. Simpson, E. Yasmin, S. Zahraah, A. (2015) E14: Our Stories, Available at: https://issuu.com/e14stories/docs/e14 our stories sp 160515

Alinsky, S. (1971) Rules for Radicals: A Pragmatic Primer for Realistic Radicals. New York: Vintage Books.

Amin, A. (2004) Regions Unbound: Towards a New Politics of Place. Geografiska Annaler B, 86, 1, 3344.

Association of Public and Land-Grant Universities (2012) The Land-Grant Tradition, Association of Public and Land-Grant Universities, Washington. 
Barnes, T. (2008) American pragmatism: Towards a geographical introduction. Geoforum, 39, 15421554.

Barnett, C. (2008) Convening publics: The parasitical spaces of public action, in Cox, K. Low, M. and Robinson, J. (eds), The SAGE Handbook of political geography, Sage, London, 403-417.

Bernstein, R. (1983) Beyond objectivity and relativism: Science, hermeneutics and praxis.

Philadelphia: University of Pennsylvania Press.

Bernstein, R. (2010) The pragmatic turn. Cambridge: Polity Press.

Bohman, J. (2002) How to make a social science practical: Pragmatism, critical social science and multi-perspectival theory. Millennium: Journal of International Studies, 31, 3, 499-524.

Booth, J. (2009) Guilty and proud of it: Poplar's rebel Councillors and Guardians 1919-25, Pontypool: Merlin Press.

Brandom, R. (2009) When pragmatism paints its blue on grey: Irony and the pragmatist enlightenment, in C. Kautzer and E. A. Mendieta (eds) Pragmatism, nation, race. Bloomington IN: Indiana University Press, 31-45.

Bridge, G. and Watson, S. (2011) Reflections on publics and cultures, in Bridge, G. and Watson, S. (eds), The New Blackwell Companion to the City, Oxford: Wiley Blackwell, 379-389.

Bunge, W. (1969) The first year of the Detroit Geographical Expedition: A personal report, in D. Peet (ed) Radical Geography: Alternative viewpoints on contemporary social issues. London: Methuen \& Co Ltd, 31-59.

Bunge, W. (1971) Fitzgerald: Geography of a revolution. Massachusetts: Schenkman Publishing Co. Burgess , E. W. (1916) The Social Survey, a Field for Constructive Service by Departments of Sociology. American Journal of Sociology, 21, 4, (Jan), 492-500.

Butler, T. and Hamnett, C. (2011) Ethnicity, class and aspiration: Understanding London's new East End. Bristol: Policy Press.

Cahill, C. (2007) The Personal is Political: Developing New Subjectivities through Participatory Action Research. Gender, Place and Culture, 14, 3, 267-292.

Cahoone, L. E. (2002) Civil society: The conservative meaning of liberal politics. Oxford: Blackwell.

Calhoun, C. (1983) The radicalism of tradition: Community strength or venerable disguise and borrowed language? American Journal of Sociology, 88, 5, 886-914. 
Cavell, S. (1980) What's the use of calling Emerson a pragmatist? in M. Dickstein (ed) The revival of pragmatism: New essays on social thought, law and culture. Durham NC: Duke University Press, 7280.

Chwalisz, C. (2015) The populist signal: Why politics and democracy need to change, London: Rowman and Littlefield International Ltd.

Colenutt, B. (1991) London Docklands Development Corporation - has the community benefitted? In M. Keith and A. Rogers (eds.) Hollow promises: Rhetoric and reality in the inner city. London: Mansell, 31-41.

Cooke, B. and Kothari, U. (2001) The case for participation as tyranny, in Cooke, B. and Kothari, U. (eds), Participation: The new tyranny? London: Zed Books, 1-15.

Dench, G. Gavron, K. and Young, M. (2006) The New East End: Kinship, Race and Conflict. London: Profile Books.

Dewey, J. (1957)[1920] Reconstruction in philosophy. Boston: Beacon Press.

Dewey, J. (1954)[1927] The public and its problems. Swallow Press and Ohio University Press.

Diggins, J. P. (1989) Pragmatism and its limits, in M. Dickstein (ed) The revival of pragmatism: New essays on social thought, law and culture. Durham NC: Duke University Press, 207-231.

Dryzek, J. (2005) Deliberative democracy in divided societies: Alternatives to agonism and amalgesia. Political Theory, 33, 2, 218-42.

Fish, S. (1989) Afterword, Truth and toilets: Pragmatism and the practices of life, in M. Dickstein (ed) The revival of pragmatism: New essays on social thought, law and culture. Durham NC: Duke University Press, 418-433.

Foster, J. (1999) Docklands: Cultures in Conflict, Worlds in Collision. London: UCL Press.

Fraser, N. (1989) Another pragmatism: Alain Locke, critical 'race' theory, and politics of culture, M. Dickstein (ed) The revival of pragmatism: New essays on social thought, law and culture. Durham NC: Duke University Press, 157-175.

Fraser, N. (1990) Rethinking the public sphere: A contribution to the critique of actually existing democracy. Social Text, 25/26, 56-80.

Fricker, M. (2007) Epistemic injustice: Power and the ethics of knowing. Oxford: Oxford University Press. 
Ganz, M. (2011) Public Narrative, Collective Action, and Power, in S. Odugbemi and T. Lee (eds) Accountability Through Public Opinion: From Inertia to Public Action. Washington: The World Bank, 273-289.

Gergen, K. (2015) From Mirroring to World-Making: Research as Future Forming. Journal for the Theory of Social Behaviour, 45, 3, $287-310$.

Gibson-Graham, J.K. (2008) Diverse economies: performative practices for 'other worlds'. Progress in Human Geography, 32, 5, 613-632.

Goodhart, D. (2017) The road to somewhere: The populist revolt and the future of politics. London: Hurst and Company.

Haidt, J. 2012, The righteous mind: Why good people are divided by politics and religion. London: Penguin

Harney, L. (2014) The living wage was a good start - but what we really need now is a living rent. Available from: http://www.theguardian.com/housing-network/2014/may/13/living-wage-livingrent-citizens-uk-housing (last accessed 1.7.14).

Harney, L. McCurry, J. Scott, J. and Wills, J. (2016) Developing 'process pragmatism' to underpin engaged research in Human Geography. Progress in Human Geography, 40, 3, 316-333.

Harney, L. and Wills, J. (2017) Infrastructures for impact: Community-University partnerships in the USA and UK. Queen Mary, University of London: Mile End Institute. Availableat:

http://mei.qmul.ac.uk/news-and-opinion/blog/items/194195.htmlHart A. and Wolff, D. (2006) Developing local 'communities of practice' through local community-university partnerships. Planning, Practice and Research, 21, 1, 121-138.

Heynen, N. and Barnes, T. (2011) Foreword to the 2011 edition: Fitzgerald then and now, in W. Bunge Fitzgerald: Geography of a Revolution [2 ${ }^{\text {nd }}$ edition]. Athens GA: The University of Georgia Press.

Honneth, A. (2007) Disrespect: The normative foundations of critical theory. Cambridge: Polity Press. Inglehart, R. and Norris, P. (2016) Trump, Brexit, and the rise of populism: Economic have-nots and cultural backlash, Harvard Kennedy School Faculty Research Working Paper Series [ONLINE] Available at: file:///C:/Users/faw438/Downloads/RWP16-026_Norris.pdf [Accessed 02.06.17] 
Kloppenberg, J.T. (1989) Pragmatism: An old name for some new ways of thinking? in M. Dickstein (ed) The revival of pragmatism: New essays on social thought, law and culture. Durham NC: Duke University Press, 83-127.

Koch, R. and Latham, A. (2013) On the hard work of domesticating a public space. Urban Studies, $50,1,6-21$.

Lake, R. W. (2017a) Urban Geography Plenary Lecture: On Poetry, pragmatism, and the urban possibility of creative democracy. Urban Geography, 38, 4, 479-494.

Lake, R. W. (197b) For creative democracy. Urban Geography, 38, 4, 507-511.

Lasch, C. (1991) The true and only heaven: Progress and its critics. New York: W.W. Norton and Co. Lasch, C. (1994) The revolt of the elites: And the betrayal of democracy. New York: W. W. Norton and Co.

Law, J. (2004) After method: Mess in social science research. London: Routledge.

Malachowski, A. (2010) The new pragmatism. Durham: Acumen.

Menand, L. (2011) The metaphysical club: A story of ideas in America. New York: Flamingo.

Massey, D. (2005) For Space. London: Sage.

Oakeshott, M (1962) Rationalism in politics and other essays. London: Methuen and Co Ltd.

Paasi, A. (2003) Region and place: Regional identity in question. Progress in Human Geography, 27, 4, 475-485.

Pain, R. and Francis, P. (2003) Reflections on participatory research. Area, 35, 1, 46-54.

Pile, S. (1995) "What we are asking for is decent human life": SPLASH, neighbourhood demands and citizenship in London's Docklands. Political Geography, 14, 2, 199-208.

Putnam, H. (1992) Realism with a human face. Cambridge MA: Harvard University Press.

Putnam, H. (1995) Renewing philosophy. Cambridge MA: Harvard University Press.

Rorty, R. (1989) Contingency, irony, solidarity. Cambridge: Cambridge University Press.

Rorty, R. (1991a) Objectivity, relativism, and truth: Philosophical papers, Volume 1. Cambridge: Cambridge University Press. 
Rorty, R. (1991b) The professor and the prophet, The American evasion of philosophy: A genealogy of pragmatism by Cornel West a review. Transition, 52, 70-78.

Rorty, R. (1998) Achieving our country: Leftist thought in the twentieth-century. Cambridge MA: Harvard University Press.

Russell, A. Cattermole, A. Hudson, R. Banks, S. Armstrong, A. Robinson, F. Pain, R. Gollan, S. and Brown, G. (2011) Sustaining community-university collaborations: The Durham University model. Gateways: International Journal of Community Research and Engagement, 4, 218-231.

Schutz, A and Miller, M. (2015) (eds) People power: The community organising tradition of Saul Alinsky. Nashville, TN: Vanderbilt University Press.

Slater, T. (ed) (2016) Unsafe space: The crisis of free speech on campus. London: Palgrave Macmillan. Studdert, D. (2016) Sociality and a proposed analytic for investigating communal being-ness. The Sociological Review, 64, 4, 622-638.

Studdert, D. and Walkerdine, V. (2016) Rethinking community research: inter-relationality, communal being and commonality. London: Palgrave Macmillan.

Torode, J. (1994) Dogfight in the Docklands: John Torode joins the 'islanders' of the British National Party as they campaign to take over a traditional Labour stronghold, The Independent [ONLINE] Available at: http://www.independent.co.uk/voices/dogfight-in-the-docklands-john-torode-joinsthe-islanders-of-the-british-national-party-as-they-1432370.html [Accessed 22.05.17].

Vertovec, S. (2007) Super-diversity and Its Implications, Ethnic and Racial Studies, 30, 6, 1024-1054.

West, C. (1989) The American evasion of philosophy: A geneology of pragmatism. Basingstoke: Macmillan.

Westbrook, R. (1991) John Dewey and American democracy. Ithaca: Cornell University Press.

Westbrook, R. (1989) Pragmatism and democracy: Reconstructing the logic of John Dewey's faith, in M. Dickstein (ed) The revival of pragmatism: New essays on social thought, law and culture. Durham NC: Duke University Press, 128-140.

Williams, J. (2016) Academic freedom in an age of conformity. Basingstoke: Palgrave Macmillan. Wills, J. (2012) The geography of community and political organisation in London today. Political Geography, 33, 2, 114-126. 
Wills, J. (2013) Place and politics, in D. Featherstone and J. Painter (eds) Spatial politics: Essays for Doreen Massey. Oxford: Wiley-Blackwell, 135-145.

Wills, J. (2016) Locating localism: Statecraft, citizenship and democracy. Bristol: Policy Press.

Wolfe, A. (1989) The missing pragmatic revival in American social science, M. Dickstein (ed) The revival of pragmatism: New essays on social thought, law and culture. Durham NC: Duke University Press, 199-206.

Young, I. M (1990) Justice and the politics of difference. Princteon, NJ: Princeton University Press.

Young, I. M. (1996) Communication and the Other: Beyond deliberative democracy, in S. Benhabib (ed) Democracy and difference: Contesting the boundaries of the political. Princeton: Princeton University Press, 120- 35.

Young, I. M. (1997) Together in difference: Transforming the logic of group political conflict, in L. McDowell (ed) Undoing Place? London: Arnold, 332-342.

Young, M. and Wilmot, P. (1957) Family and kinship in East London. London: Routledge and Kegan Paul.

\footnotetext{
i Participants took part in 4 workshops over a period of 3 months in which they engaged in a series of discussions amongst themselves around the 'story of E14'. Between workshops, participants were asked to think about and write their own personal story, and talk to at least 5 people from the E14 area to find other stories that they were willing to share. Stories were chosen that highlighted positive instances of local people acting to make a difference, no matter how 'big' or 'small'. The stories were written by participants and sent back to the people who shared them to validate them before being compiled in the book.
} 